\title{
Optimal conditions for levan biopolymer production and its use in the synthesis of bactericidal levan- $\mathrm{ZnO}$ nanocomposite
}

\author{
MOJTABa TARAN $^{1}$, MaHSa LOTFI ${ }^{2}$, MohSEn SAFAeI ${ }^{3 *}$ \\ ${ }^{1}$ Department of Nanobiotechnology, Faculty of Science, Razi University, Kermanshah, Iran \\ ${ }^{2}$ Laboratory of Microbiology, Department of Biology, Faculty of Science, Razi University, Kermanshah, Iran \\ ${ }^{3}$ Advanced Dental Sciences Research Laboratory, School of Dentistry, Kermanshah University of Medical Sciences, Kermanshah, Iran
}

\begin{abstract}
With the ever-increasing resistance of pathogens to various antibiotics, it has become critically important to find novel biocompatible antibacterial agents. This research focuses on the optimization of the biological synthesis of levan biopolymer using the Taguchi method in order to produce levan- $\mathrm{ZnO}$ nanocomposite. Attempts have been made to synthesize this nanocomposite to improve the antibacterial activity of $\mathrm{ZnO}$ nanoparticles. Optimization of growth conditions led to the improved levan-producing capabilities of the Zymomonas mobilis PTCC 1718 strain $(57 \mathrm{~g} / \mathrm{l})$. Molten salt and in situ methods were applied for the synthesis of $\mathrm{ZnO}$ nanoparticles and levan- $\mathrm{ZnO}$ nanocomposite, respectively. Ultraviolet-visible (UV-vis) spectroscopy, Fourier transform infrared (FTIR) spectroscopy, and scanning electron microscopy (SEM) confirmed the formation of levan biopolymer, $\mathrm{ZnO}$ nanoparticles, and levan- $\mathrm{ZnO}$ nanocomposite. Antibacterial analysis showed that the formation of nanocomposite improved the antibacterial activity of $\mathrm{ZnO}$ nanoparticles. The present study has demonstrated that levan- $\mathrm{ZnO}$ nanocomposite characterized by the capability to destroy Gram-positive and Gram-negative microorganisms might be utilized as an antibacterial agent in the medical, pharmaceutical, dentistry, and food industries.
\end{abstract}

Key words: nanocomposite, levan biopolymer, zinc oxide, antibacterial, Zymomonas mobilis, Taguchi method

\section{Introduction}

One of the main challenges facing the global community today is discovering effective therapies for cancer (Mozaffari et al., 2016; Mozaffari et al., 2017), chronic pains (Sharifi et al., 2017), chronic kidney disease (Nomani et al., 2016), autoimmune diseases (Mozaffari et al., 2018), and microbial infections (Taran et al., 2018; Imani and Safaei, 2019). Microbial infections are historically considered as major pathogenic factors causing mortality around the world ( $\mathrm{Li}$ and Webster, 2018). Nowadays, due to the increased bacterial resistance to antibiotics, it has become necessary to find innovative ways of eliminating bacteria. Applying nanoparticle based materials on the grounds of their features and bene- fits as antimicrobial compounds has received increasing attention (Beyth et al., 2015; Safaei and Taran, 2017).

Levan is an exopolysaccharide with a molecular weight of $107 \mathrm{Da}$; it is made up of about 60000 units of fructose. The main chain is formed by $\beta$-links $(2,6)$; the branches are generated by $\beta-1,2$ bindings (Alegre et al., 2005; Arvidson et al., 2006). Levan biopolymers are obtained in different ways, of which one is its production by a wide range of bacteria during the enzymatic transfructosylation reaction. Zymomonas mobilis is an important bacterium in the microbial production of levan biopolymer. It is a Gram-negative rod-shaped bacterium with a length of 2-6 $\mu \mathrm{m}$ and a width of $1-1.4 \mu \mathrm{m}$; it is nonsporulating.

\footnotetext{
* Corresponding author: Advanced Dental Sciences Research Laboratory, School of Dentistry, Kermanshah University of Medical Sciences, Kermanshah, Iran; e-mail: mohsen_safaei@yahoo.com
} 
Appropriate viscosity and stability in the face of $\mathrm{pH}$ adjustments, water and oil solubility, solubility in organic solvents, heat resistance (melting point temperature of $225^{\circ} \mathrm{C}$ ), high water holding capacity and capacity to hold chemical materials, as well as favorable biological characteristics, has made levan a unique polymer that is indispensable in many fields. Levan as an emulsifier, stabilizer, an encapsulating agent, and a concentration factor is used in several sectors of medical, pharmaceutical, and food industries (Bekers et al., 2005; Srikanth et al., 2015). It serves as an anti-inflammatory and immunomodulatory agent, blood plasma substitute, antitumor, antioxidant, and anti-AIDS compound in medication $(\mathrm{Ab}-$ del-Fattah et al., 2012; Silbir et al., 2014). Levan biopolymer is also applied for drug delivery, improving the flavor of tablets and solubility of capsules, and generating a more rapid medicinal response (Srikanth et al., 2015). The exopolysaccharide is critically important in the industry because of its sweetening and antibacterial characteristics. Byun et al (2014) reported the antibacterial characteristics of levan compounds with low molecular weight. The widespread use of levan in different industries has transformed it into a multipurpose polymer (Srikanth et al., 2015).

$\mathrm{ZnO}$ nanoparticles differ from each other in terms of size, shape, and crystal structure. These features depend on substrate type and its concentration, the kind of organic solvents used, applied temperature, and reaction time during synthesis (Altunbek et al., 2014). Zinc oxide is important due to its interesting characteristics such as chemical stability, high UV absorption, photostability, biocompatibility, and diversity of particles structures (Kolodziejczak-Radzimska and Jesionowski, 2014). It is used in different industries such as medical, pharmaceutical, cosmetics, textiles, and electronics (Mishra and Adelung, 2018). In recent years, inorganic compounds including metal oxides have received increased attention because of their high stability in harsh conditions and the fact that they are not harmful to humans, animals, and the environment (Stoimenov et al., 2002). Metal oxide nanoparticles (NPs) including $\mathrm{ZnO}$ have selective toxicity to bacteria while minimally affecting human cells. The reduced size of $\mathrm{ZnO} N P s$ increases their antibacterial characteristics (Seil and Webster, 2011).

Nanocomposite is a material consisting of two or more distinct phases where at least one of them is in nanoscale (between 1 to $100 \mathrm{~nm}$ ). Nowadays, nanocomposites are the subject of intense research owing to their unique mechanical, chemical, and physical properties (Camargo et al., 2009). Synthesizing polymeric nanocomposites using NPs can improve the optical and mechanical properties of the components of the nanocomposites; this improvement is because of the strong internal interaction between the organic polymer and the inorganic nanoparticles which have a large surface area and quantum effect (Sato et al., 2008; Safaei et al., 2019).

To our knowledge, no levan-ZnO nanocomposite has been synthesized to date; thus, its antibacterial effects have not yet been evaluated. The goal of this study was to optimize levan biopolymer production at lower costs, synthesize $\mathrm{ZnO} \mathrm{NPs}$, and manufacture levan- $\mathrm{ZnO}$ nanocomposite, as well as investigate its antibacterial effect on Escherichia coli and Staphylococcus aureus pathogens.

\section{Material and methods}

\section{Levan polymer production}

The bacterial Zymomonas mobilis PTCC 1718 was provided by the Iranian Research Organization for Science and Technology (IROST) and incubated at $30^{\circ} \mathrm{C}$ for $48 \mathrm{~h}$. The grown colonies were transferred to the inoculating culture media containing sucrose $(50 \mathrm{~g} / 1)$, yeast extract $(7 \mathrm{~g} / \mathrm{l}), \mathrm{K}_{2} \mathrm{HPO}_{4}(2.5 \mathrm{~g} / \mathrm{l}),\left(\mathrm{NH}_{4}\right)_{2} \mathrm{SO}_{4}(1.6 \mathrm{~g} / \mathrm{l})$, $\mathrm{MgSO}_{4} \cdot 7 \mathrm{H}_{2} \mathrm{O}(1 \mathrm{~g} / \mathrm{l})$, and incubated for $24 \mathrm{~h}$ at $28^{\circ} \mathrm{C}$ without air and stirring. The Taguchi method and Qualitek-4 software were used to predict the best conditions for the production of levan. In this study, the effects of three factors (i.e., sucrose, yeast extract, and potassium phosphate) were investigated at three levels of levan synthesis (Table 1). The medium used for producing levan contained sucrose $(150,200$, or $300 \mathrm{~g} / \mathrm{l})$, yeast extract $(1,1.5$, or $2 \mathrm{~g} / \mathrm{l}), \mathrm{K}_{2} \mathrm{HPO}_{4}(0.5,1$, or $1.5 \mathrm{~g} / \mathrm{l})$, $\left(\mathrm{NH}_{4}\right)_{2} \mathrm{SO}_{4}(1 \mathrm{~g} / \mathrm{l})$, and $\mathrm{MgSO}_{4} 7 \mathrm{H}_{2} \mathrm{O}(0.5 \mathrm{~g} / 1)$. Following 20 min sterilization at $121^{\circ} \mathrm{C}$, the medium was inoculated with bacterial culture $(2-5 \%)$ and kept in an incubator without shaking at $28^{\circ} \mathrm{C}$ for $48 \mathrm{~h}$. Then, the samples were centrifuged for $10 \mathrm{~min}$ at $5000 \mathrm{~g}$. The supernatant was concentrated at $85-90^{\circ} \mathrm{C}$ in a water bath in order to reduce the centrifuged volume to $1 / 3$ (Silbir et al., 2014).

\section{Levan polymer extraction}

To extract the levan polymer, $90 \mathrm{ml}$ of cold ethanol $(96 \%)$ were added per $100 \mathrm{ml}$ of concentrated solution. The samples were centrifuged at $4000 \mathrm{rpm}$ following $2 \mathrm{~h}$ 
Table 1. The Taguchi design of experiments and levan biopolymer production by Zymomonas mobilis

\begin{tabular}{|c|c|c|c|c|c|c|c|c|c|c|}
\hline \multirow[t]{2}{*}{ Experiment } & \multicolumn{3}{|c|}{$\begin{array}{c}\text { Yeast extract } \\
{[\mathrm{g} / \mathrm{l}]}\end{array}$} & \multicolumn{3}{|c|}{$\begin{array}{c}\mathrm{KH}_{2} \mathrm{PO}_{4} \\
{[\mathrm{~g} / \mathrm{l}]}\end{array}$} & \multicolumn{3}{|c|}{$\begin{array}{c}\text { Sucrose } \\
{[\mathrm{g} / \mathrm{l}]}\end{array}$} & \multirow{2}{*}{$\begin{array}{c}\text { Levan } \\
{[\mathrm{g} / \mathrm{l}]}\end{array}$} \\
\hline & 1 & 1.5 & 2 & 0.5 & 1 & 1.5 & 150 & 200 & 300 & \\
\hline 1 & \multicolumn{3}{|c|}{1} & \multicolumn{3}{|c|}{0.5} & \multicolumn{3}{|c|}{150} & 21.66 \\
\hline 2 & \multicolumn{3}{|c|}{1} & \multicolumn{3}{|c|}{1} & \multicolumn{3}{|c|}{200} & 19.00 \\
\hline 3 & \multicolumn{3}{|c|}{1} & \multicolumn{3}{|c|}{1.5} & \multicolumn{3}{|c|}{300} & 57.00 \\
\hline 4 & \multicolumn{3}{|c|}{1.5} & \multicolumn{3}{|c|}{0.5} & \multicolumn{3}{|c|}{200} & 34.33 \\
\hline 5 & \multicolumn{3}{|c|}{1.5} & \multicolumn{3}{|c|}{1} & \multicolumn{3}{|c|}{300} & 26.33 \\
\hline 6 & \multicolumn{3}{|c|}{1.5} & \multicolumn{3}{|c|}{1.5} & \multicolumn{3}{|c|}{150} & 8.16 \\
\hline 7 & \multicolumn{3}{|c|}{2} & \multicolumn{3}{|c|}{0.5} & \multicolumn{3}{|c|}{300} & 41.33 \\
\hline 8 & \multicolumn{3}{|c|}{2} & \multicolumn{3}{|c|}{1} & \multicolumn{3}{|c|}{150} & 11.60 \\
\hline 9 & \multicolumn{3}{|c|}{2} & \multicolumn{3}{|c|}{1.5} & \multicolumn{3}{|c|}{200} & 15.83 \\
\hline
\end{tabular}

of refrigeration. To determine the quantity of levan extracted, the sediments were put in an oven at $80^{\circ} \mathrm{C}$ to be dried and then weighed (De Oliveira et al., 2007; Dos Santos et al., 2013).

\section{Synthesis of $Z n O$ nanoparticles}

$\mathrm{ZnO}$ NPs were synthesized using the molten salt method. For this purpose, zinc chloride salt ( $83 \mathrm{~g}$ ), sodium hydroxide $(19.01 \mathrm{~g})$ and potassium hydroxide $(19.01 \mathrm{~g})$ were combined, and placed in an oven at $220^{\circ} \mathrm{C}$ for $45 \mathrm{~min}$; the resulting mix was then cooled down to room temperature. Subsequently, the mix was rinsed in hot distilled water and centrifuged to remove alkali metal salts. The centrifuged sediment was placed in an oven at $100^{\circ} \mathrm{C}$ for $2 \mathrm{~h}$ to remove moisture. Finally, a white color powder containing $\mathrm{ZnO}$ NPs was obtained (Sikalidas, 2011).

\section{Levan- $\mathrm{ZnO}$ nanocomposite synthesis}

$\mathrm{ZnO}$ NPs were homogenized in deionized water by a sonicator. Then, they were added to the biopolymer matrix in deionized water and placed on a stirrer for $1 \mathrm{~h}$. In the next phase, the samples were transferred to a sonicator bath for $30 \mathrm{~min}$. After oven-drying at $40^{\circ} \mathrm{C}$ for $48 \mathrm{~h}$, the nanocomposite powder containing levan polymer and $\mathrm{ZnO}$ NPs was obtained (Perez-Altamar and Perales-Perez, 2014).

\section{Characterization}

The UV-vis spectra were prepared for the synthesized levan biopolymer, $\mathrm{ZnO} \mathrm{NPs}$, and levan- $\mathrm{ZnO}$ nanocompo- site in the range 200 to $800 \mathrm{~nm}$ by Agilent spectrophotometer. The FTIR spectra of the synthesized levan biopolymer, $\mathrm{ZnO} \mathrm{NPs}$, and levan- $\mathrm{ZnO}$ nanocomposite were prepared by an alpha spectrometer (Bruker, Germany). SEM images of the levan- $\mathrm{ZnO}$ nanocomposite were obtained by a TESCAN scanning electron microscope (Czech Republic).

\section{Antibacterial activity}

The antibacterial activity of the levan biopolymer, $\mathrm{ZnO} \mathrm{NPs}$, and levan-ZnO nanocomposite on Staphylococcus aureus from the Gram-positive bacteria and Escherichia coli from the Gram-negatives were examined by the disc diffusion method. For this purpose, a suspension of bacteria with an approximate concentration of $10^{8} \mathrm{CFU}$ (colony forming units)/ml was prepared and cultured on a nutrient agar medium. Then, four discs containing the levan biopolymer, $\mathrm{ZnO} \mathrm{NPs}$, levan- $\mathrm{ZnO}$ nanocomposite, and Gentamycin (positive control) were placed on the plates and incubated for $24 \mathrm{~h}$. All the tests were carried out with three experiment repetitions and three replicates of each experiment.

\section{Results}

\section{Levan production}

To determine the optimum conditions for levan production by $Z$ ymomonas mobilis PTCC 1718 , the weight of the levan obtained from the nine separate experiments was measured (Table 1). The maximum production of microbial levan biopolymer, obtained in experi- 
Table 2. The main effects of different levels of yeast extract, $\mathrm{KH}_{2} \mathrm{PO} 4$ and sucrose on levan biopolymer production by Zymomonas mobilis

\begin{tabular}{l|c|c|c}
\hline \multicolumn{1}{c|}{ Factors } & $\begin{array}{c}\text { Level 1 } \\
\text { [value] }\end{array}$ & $\begin{array}{c}\text { Level 2 } \\
\text { [value] }\end{array}$ & $\begin{array}{c}\text { Level 3 } \\
\text { [value] }\end{array}$ \\
\hline Yeast extract & 32.53 & 22.94 & 22.92 \\
\hline $\mathrm{KH}_{2} \mathrm{PO}_{4}$ & 32.44 & 18.98 & 26.99 \\
\hline Sucrose & 13.81 & 23.05 & 41.55 \\
\hline
\end{tabular}

Table 3. Estimation of the effects of interacting factor pairs on levan biopolymer production by Zymomonas mobilis

\begin{tabular}{l|c|c}
\hline Interacting factor pairs & $\begin{array}{c}\text { Desirable } \\
\text { levels }\end{array}$ & $\begin{array}{c}\text { Severity index } \\
{[\%]}\end{array}$ \\
\hline Yeast extract $\times$ sucrose & $(3.1)$ & 29.51 \\
\hline Yeast extract $\times \mathrm{KH}_{2} \mathrm{PO}_{4}$ & $(3.1)$ & 5.46 \\
\hline $\mathrm{KH}_{2} \mathrm{PO}_{4} \times$ sucrose & $(3.3)$ & 5.39 \\
\hline
\end{tabular}

ment 3 , was $57 \mathrm{~g} / \mathrm{l}$. In this experiment, the most appropriate concentrations of the yeast extract, potassium phosphate, and carbon source to produce levan were $1 \mathrm{~g} / \mathrm{l}, 0.5 \mathrm{~g} / \mathrm{l}$, and $300 \mathrm{~g} / \mathrm{l}$, respectively. The effects of different levels of the yeast extract $(1,1.5$, and $2 \mathrm{~g} / \mathrm{l})$, $\mathrm{KH}_{2} \mathrm{PO}_{4}(0.5,1$, and $1.5 \mathrm{~g} / \mathrm{l})$, and sucrose $(150,200$, $300 \mathrm{~g} / \mathrm{l})$ on levan production are presented in Table 2. Level 1 for yeast extract (32.53) and potassium phosphate (32.44), and level 3 for sucrose (41.55) had the best effect on levan production by Zymomonas mobilis. Estimating the effects of interacting factor pairs on levan biopolymer production by $Z$ ymomonas mobilis revealed that the interactions between the yeast extract and sucrose were the most relevant pair influencing the amount of levan produced (29.51\%). On the other hand, potassium phosphate and sucrose had the lowest level of interaction (5.39\%), which is very close to the interaction between the yeast extract and potassium phosphate (5.46\%) (Table 3$)$. Table 4 shows the analysis of variance (ANOVA) of parameters influencing levan production by Zymomonas mobilis. Yeast extract as a source of nitrogen and potassium phosphate had no significant effect on the amount of levan produced; sucrose as a carbon source was the main factor affecting the amount of levan (533.450). After evaluating the effect of the studied factors and their interactions, the best conditions for producing levan biopolymer were determined using the Ta- guchi method (Table 5). The results showed that carbon source, yeast extract, and potassium phosphate, with a contribution of $15.41,6.42$, and $6.30 \%$, respectively, resulted in the highest production of microbial levan biopolymer. Based on the prediction by the Taguchi method, level 3 for sucrose $(300 \mathrm{~g} / \mathrm{l})$ and level 1 for yeast extract $(1 \mathrm{~g} / \mathrm{l})$ and potassium phosphate $(0.5 \mathrm{~g} / \mathrm{l})$ were presented as the most suitable levels for producing levan biopolymer.

\section{Characteristics of levan- $\mathrm{ZnO}$ nanocomposite and its components}

UV-vis spectrophotometry was used to study the optical properties of the synthesized levan biopolymer, $\mathrm{ZnO}$ $\mathrm{NPs}$, and levan- $\mathrm{ZnO}$ nanocomposite. Absorption measurements were done in the range 250 to $600 \mathrm{~nm}$. The observed changes in the peaks indicated that $\mathrm{ZnO}$ NPs were coated with levan biopolymers (Fig. 1).

In order to ensure that the production of levan biopolymer, the synthesis of $\mathrm{ZnO} \mathrm{NPs}$, and the formation of levan- $\mathrm{ZnO}$ nanocomposite occurred, FTIR spectrums were recorded for each sample (Fig. 2). In the range 900 to $1200 \mathrm{~cm}^{-1}$, the observed peaks were due to $\mathrm{C}-\mathrm{C}$, $\mathrm{C}-\mathrm{O}, \mathrm{C}-\mathrm{O}-\mathrm{H}$, and $\mathrm{C}-\mathrm{O}-\mathrm{C}$ bonds. The peak at $1063 \mathrm{~cm}^{-1}$ confirmed the production of levan. Furthermore, the peak at $435 \mathrm{~cm}^{-1}$ confirmed the presence of $\mathrm{ZnO}$ NPs. Considering the observed changes in the peaks of levan- $\mathrm{ZnO}$ nanocomposite compared to its components, the synthesis of nanocomposite was confirmed.

The SEM images of $\mathrm{ZnO}$ nanoparticles and levan- $\mathrm{ZnO}$ nanocomposite are presented in Figure 3. The SEM image of the nanocomposite shows that the $\mathrm{ZnO}$ nanoparticles were coated on the levan biopolymer and were desirably dispersed within the matrix.

\section{Antibacterial analysis of the levan-ZnO nanocomposite and its components}

The antibacterial activity of levan biopolymer, $\mathrm{ZnO}$ $\mathrm{NPs}$, and levan- $\mathrm{ZnO}$ nanocomposite against two pathogens (Escherichia coli and Staphylococcus aureus) were studied (Table 6). The inhibition zones of levan- $\mathrm{ZnO}$ nanocomposite: $16.00 \mathrm{~mm}$ and $14.66 \mathrm{~mm}$ for Gram-positive and Gram-negative bacteria, respectively, were significantly bigger than those of $\mathrm{ZnO}$ NPs $(12.66 \mathrm{~mm}$ and $10.33 \mathrm{~mm}$ for Gram-positive and Gram-negative bacteria, respectively) and levan biopolymer ( $0 \mathrm{~mm}$ for both tested bacteria) $(P<0.05)$. No significant difference was 
Table 4. Analysis of variance of the Taguchi experiment results for levan biopolymer production by Zymomonas mobilis

\begin{tabular}{l|c|c|c|c|c}
\hline \multicolumn{1}{c|}{ Factors } & DOF & Sum of squares & Variance & Pure sum & Percent [\%] \\
\hline Yeast extract & 2 & 185.22 & 92.61 & 0.00 & 0.00 \\
\hline $\mathrm{KH}_{2} \mathrm{PO}_{4}$ & 2 & 275.21 & 137.61 & 0.00 & 0.00 \\
\hline Sucrose & 2 & 1197.63 & 598.81 & 893.46 & 45.53 \\
\hline
\end{tabular}

Table 5. Predicted optimum conditions for levan biopolymer production by Zymomonas mobilis

\begin{tabular}{l|c|c}
\hline \multicolumn{1}{c|}{ Factors } & Level & $\begin{array}{c}\text { Contribution } \\
{[\%]}\end{array}$ \\
\hline Yeast extract & 1 & 6.42 \\
\hline $\mathrm{KH}_{2} \mathrm{PO}_{4}$ & 1 & 6.30 \\
\hline Sucrose & 3 & 15.41 \\
\hline Total contribution from all factors & 28.13 \\
\hline Current grand average of performance & 26.14 \\
\hline Biopolymer production at optimum conditions & 54.27 \\
\hline
\end{tabular}

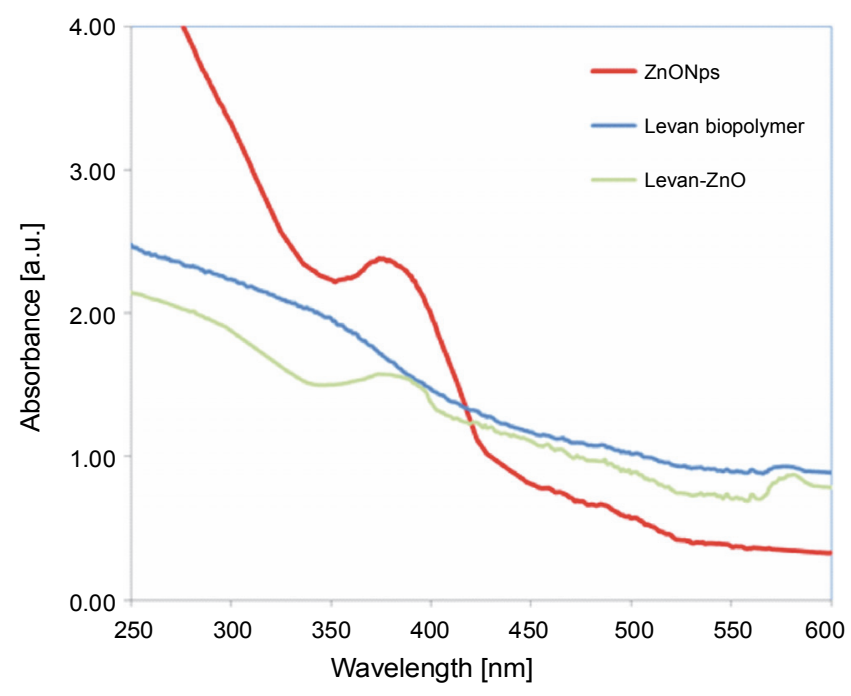

Fig. 1. UV-Vis spectroscopic analysis of $\mathrm{ZnO}$ nanoparticle, levan biopolymer, and levan- $\mathrm{ZnO}$ nanocomposite

observed in the antibacterial activity level of levan- $\mathrm{ZnO}$ nanocomposite and the antibiotic Gentamycin antibiotic (17.66 $\mathrm{mm}$ for Gram-positive and $15.33 \mathrm{~mm}$ for Gramnegative bacteria) against these pathogens $(P>0.05)$. The decrease in the growth of bacteria in the presence of the levan- $\mathrm{ZnO}$ nanocomposite in comparison with its components indicates its improved antibacterial ability in preventing the growth of both pathogens.

\section{Discussion}

As levan biopolymer is used in various fields, it is important to optimize its production. The results of this study show that the maximum level of levan production was obtained from Zymomonas mobilis PTCC 1718 in experiment 3 (57 g/1 - Table 1$)$. Levan culturing and production required the presence of three factors (carbon source, yeast extract, and potassium phosphate) in the growth medium; the tests revealed that sucrose had the greatest influence on levan production compared to the two other factors such that by increasing sucrose concentration, levan production also improved (Table 2). Compared to the previous studies on this subject, microbial levan production was at a higher concentration in this research (Melo et al., 2007). The authors studied the impact of four factors: temperature, agitation, sucrose, and yeast extract concentration on the production of levan by Zymomonas mobilis. The maximum amount of levan produced was $14.67 \mathrm{~g} / \mathrm{l}$, which was obtained at a temperature of $20^{\circ} \mathrm{C}$, agitation rate of $100 \mathrm{rpm}$, sucrose concentration of $250 \mathrm{~g} / \mathrm{l}$; the concentration of yeast extract was stated to have no effect (Melo et al., 2007). In another study, Silbir et al. (2014) studied levan biopolymer production by Zymomonas mobilis B-14023 in batch and continuous fermentation systems. In both 
A
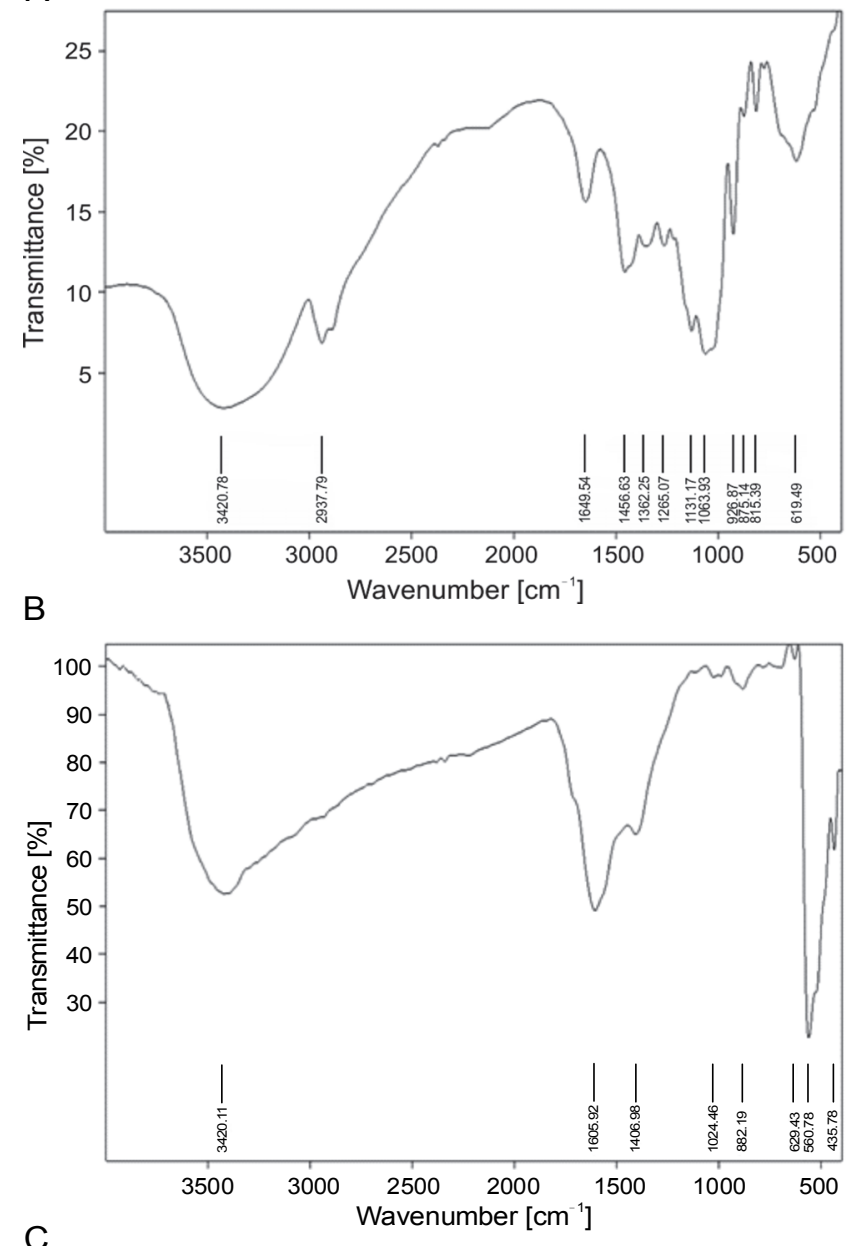

C

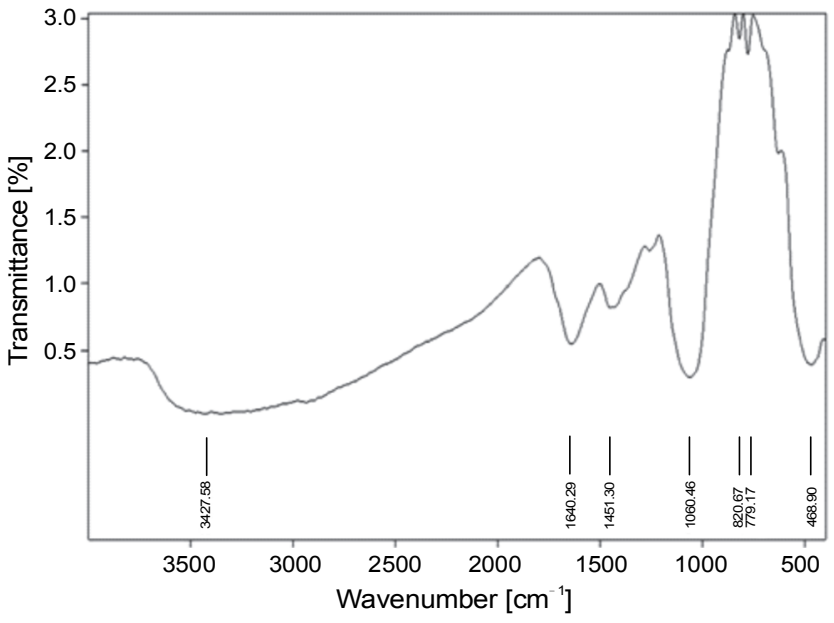

Fig. 2. A) FTIR analysis of levan biopolymer, B) $\mathrm{ZnO}$ nano particle, and $\mathrm{C}$ ) levan- $\mathrm{ZnO}$ nanocomposite

systems, sucrose and numerous sources of nitrogen were used; yeast extract was found to be the best source of nitrogen. The authors noted that the maximum production of levan biopolymer in batch and continuous fermentation systems were $40.2 \mathrm{~g} / 1$ and $31.8 \mathrm{~g} / \mathrm{l}$, res- pectively. De Oliveira et al. (2007) used molasses, sucrose, and cane extract as a source of carbon to produce levan by Zymomonas mobilis ATCC 31821 . The maximum production of levan biopolymer $(21.685 \mathrm{~g} / \mathrm{l})$ was observed in the treatment containing sucrose while minimum production was observed in the presence of molasses $(2.533 \mathrm{~g} / \mathrm{l})$ as the source of carbon. Moreover, earlier studies demonstrated that bacterial species and the amount of initial substrate play direct roles in producing levan biopolymer. Levan biopolymer production by Bacillus subtilis bacterium was reported to be $14.31 \mathrm{~g} / 1$ by Shih et al. (2005); while Ghaly et al. (2007) reported that the amount of this biopolymer extraction from $\mathrm{Ba}$ cillus licheniformis was $0.36 \mathrm{l} / \mathrm{g}$. In a study conducted by Khanafari et al. (2010), the amount of extracted biopolymer from Bacillus polymyxa was $19.5 \mathrm{~g} / \mathrm{l}$.

In the present study, microbial levan biopolymer synthesis was optimized as a biodegraded polymer and then used for coating $\mathrm{ZnO}$ NPs in the synthesis of an antibacterial nanocomposite. By applying FTIR analysis and UV-vis spectroscopy, the synthesis of levan biopolymer, $\mathrm{ZnO} \mathrm{NPs,} \mathrm{and} \mathrm{levan-ZnO} \mathrm{nanocomposite} \mathrm{were} \mathrm{confirmed}$ (Fig. 1 and Fig. 2). The desirable antibacterial properties of the synthesized levan- $\mathrm{ZnO}$ nanocomposite make it suitable for medical, environmental, food industry, and pharmaceutical applications.

An important application of the synthesized nanocomposite, taking into consideration the antibacterial properties of levan biopolymer and $\mathrm{ZnO}$, is its use as a new antibiotic. Since pathogens have become increasingly resistant to available antibiotics, finding a new biocompatible antibiotic is of great importance. While studying the antibacterial activity of levan- $\mathrm{ZnO}$ nanocomposite against two pathogens of Escherichia coli and Staphylococcus aureus, it was observed that the nanocomposite had the ability to prevent the growth of both pathogens (Table 6). Recent developments in the field of nanotechnology, especially in the making of nanoparticles of different shapes and sizes, have led to the establishment of a new group of antibacterial agents (Helmlinger et al., 2016; Taran et al., 2016). Nanoparticles have a higher surface per volume ratio compared to larger particles with the same chemical composition, which makes them more active biologically (Rad et al., 2018). Nanocomposites are nanostructures that have been regarded and studied as a new class of antibiotics in recent years due to their unique features. Droval et al. (2008) 

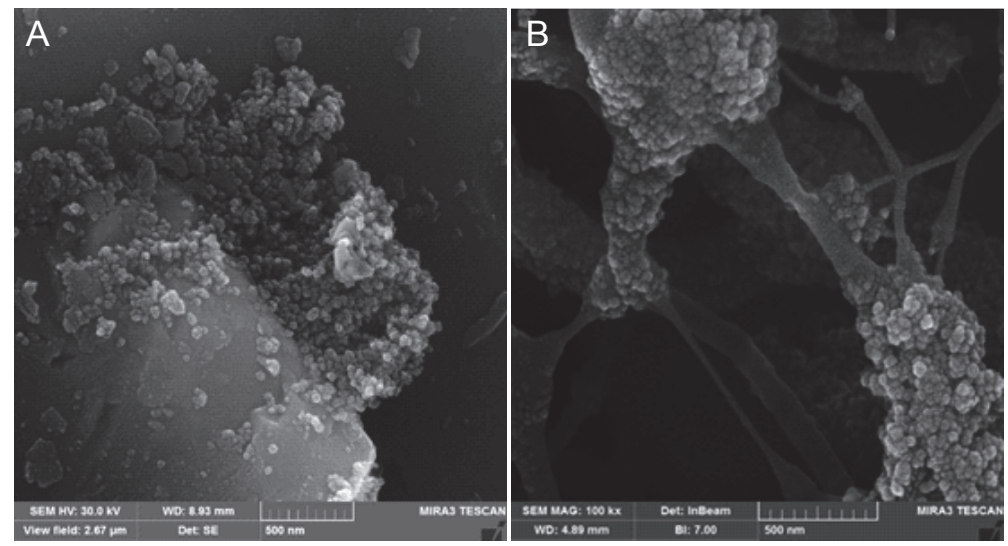

Fig. 3. A) SEM analysis of $\mathrm{ZnO}$ nanoparticles and $\mathrm{B}$ ) levan- $\mathrm{ZnO}$ nanocomposite; the image of the nanocomposite shows that the nanoparticles are coated on the biopolymer

Table 6. Comparison of antibacterial activity of levan- $\mathrm{ZnO}$ nanocomposite with $\mathrm{ZnO}$ nanoparticles and levan polymer

\begin{tabular}{l|c|c}
\hline \multirow{2}{*}{ Factors } & $\begin{array}{c}\text { Gram-positive bacteria } \\
\text { (Staphylococcus aureus })\end{array}$ & $\begin{array}{c}\text { Gram-negative bacteria } \\
\text { (Escherichia coli })\end{array}$ \\
\cline { 2 - 3 } & $\begin{array}{c}\text { zone of inhibition } \\
{[\mathrm{mm}]}\end{array}$ & $\begin{array}{c}\text { zone of inhibition } \\
{[\mathrm{mm}]}\end{array}$ \\
\hline $\mathrm{ZnO}$ & $12.66^{\mathrm{b}}$ & $10.33^{\mathrm{b}}$ \\
\hline Levan & $0.00^{\mathrm{c}}$ & $0.00^{\mathrm{c}}$ \\
\hline Levan-ZnO & $16.00^{\mathrm{a}}$ & $14.66^{\mathrm{a}}$ \\
\hline Gentamycin & $17.66^{\mathrm{a}}$ & $15.33^{\mathrm{a}}$ \\
\hline Standard error of the mean & 0.39 & 0.31 \\
\hline
\end{tabular}

synthesized nanocomposites using two polymers of polyamide 6) PA6 (and low-density polyethylene) LDPE (as a matrix of $\mathrm{ZnO} \mathrm{NPs}$ and examined their antimicrobial properties against Escherichia coli and Staphylococcus aureus pathogens. The authors found that PA6-zinc oxide nanocomposite had better antibacterial properties compared to pure $\mathrm{ZnO}$ particles (Droval et al., 2008). In another study, Hadory and Shim (2013) synthesized a hybrid compound of $\mathrm{ZnO}$ and chitosan using a precipitation method. The authors examined the antibacterial activity of this nanocomposite against $E$. coli and observed that it had the ability to eradicate this bacterium (Haldorai and Shim, 2013). Perez-Altamar and PeralesPerez (2014) successfully synthesized chitosan/cellulose-ZnO nanocomposite; they examined its antibacterial activity and reported the ability of this nanocomposite to prevent the growth of $E$. coli pathogen. Dhillon et al. (2014) synthesized $\mathrm{ZnO}$-chitosan nanocomposite using two methods of spray drying and depositing. The antibacterial effects of the synthesized nanocomposite were examined against the pathogens of Micrococcus luteus, Candida albicans, and Staphylococcus aureus. The maximum antimicrobial effect against $M$. luteus and $S$. aureus was observed at concentrations of 0.156 to $0.625 \mathrm{mg} / \mathrm{ml}$ of the nanocomposite (Dhillon et al., 2014).

The results of the present study and the previous ones described here reveal that the formation of nanocomposites composed of $\mathrm{ZnO}$ nanoparticles and a polymer improves their antimicrobial properties. Considering their tendency to agglomerate, the use of biopolymers as biodegradable stabilizers can prevent this agglomeration and increase effective surface area against pathogens. To our knowledge, no study has reported the synthesis of a levan- $\mathrm{ZnO}$ nanocomposite yet. Therefore, the nanocomposite was synthesized and tested as a new antibacterial substance in this study. This novel nanocompo- 
site with antibacterial properties has a great potential for use in various fields, for example, in medical, food, pharmaceutical, dentistry, and other industries.

\section{Conclusions}

Levan was produced in optimum conditions by $Z y m o-$ monas mobilis PTCC 1718. In optimum conditions, the amount of extracted biopolymer was $57 \mathrm{~g} / \mathrm{l}$; this study showed that there is a direct relation between sucrose concentration and the production of levan biopolymer. The production of levan biopolymer, the synthesis of nanoparticles, and the formation of nanocomposite were all confirmed by UV, FTIR and SEM analysis. The results of an antibacterial test showed the ability of levan$\mathrm{ZnO}$ nanocomposite in reducing the growth of pathogenic microorganisms of Escherichia coli and Staphylococcus aureus. Based on the results of this study, it seems profitable to use levan- $\mathrm{ZnO}$ nanocomposite as a practical antibacterial substance in various industries.

\section{References}

Abdel-Fattah A.M., Gamal-Eldeen A.M., Helmy W.A., Esawy M.A. (2012) Antitumor and antioxidant activities of levan and its derivative from the isolate Bacillus subtilis NRC1aza. Carbohydr. Polym. 89(2): 314-322.

Alegre R.M., Wendt R., Rigo M. (2005) Levan production by isolated mutants of Zymomonas mobilis. Rev. Cienc. Exatas. Nat. 7(1): 103-112.

Altunbek M., Baysal A., Çulha M. (2014) Influence of surface properties of zinc oxide nanoparticles on their cytotoxicity. Colloids. Surf B. 121: 106-113.

Arvidson S.A, Rinehart B.T., Gadala-Maria F. (2006) Concentration regimes of solutions of levan polysaccharide from Bacillus sp. Carbohydr. Polym. 65(2): 144-149.

Bekers M., Upite D., Kaminska E., Laukevics J., Grube M., Vigants A., Linde R. (2005) Stability of levan produced by Zymomonas mobilis. Process. Biochem. 40(5): 1535-1539.

Beyth N., Houri-Haddad Y., Domb A., Khan W., Hazan R. (2015) Alternative antimicrobial approach: nano-antimicrobial materials. Evid. Based. Complement. Alternat. Med. 13: 1-16.

Byun B.Y., Lee S.J., Mah J.H. (2014) Antipathogenic activity and preservative effect of levan ( $\beta 2,6$ fructan), a multifunctional polysaccharide. Int. J. Food Tech. 49(1): 238-245.

Camargo P.H., Satyanarayana K.G., Wypych F. (2009) Nanocomposites: synthesis, structure, properties and new application opportunities. Mater. Res. 12(1):1-39.

De Oliveira M.R., Da Silva R.S., Buzato J.B., Celligoi M.A. (2007) Study of levan production by Zymomonas mobilis using regional low-cost carbohydrate sources. Biochem. Eng. J. 37: 177-183.
Dhillon G.S., Kaur S., Brar S.K. (2014) Facile fabrication and characterization of chitosan-based zinc oxide nanoparticles and evaluation of their antimicrobial and antibiofilm activity. Int. Nano. Lett. 4: 1-11.

Dos Santos L.F., De Melo B.C., Paiva W.M., Borsato D., Da Silva M.C., Celligoi M.P. (2013) Characterization and optimization of levan production by Bacillus subtilis NATTO. Rom. Biotech. Lett. 18(4): 8413-8422.

Droval G., Aranberri I., Bilbao A., German L., Verelst M., Dexpert-Ghys J. (2008) Antimicrobial activity of nanocomposites: poly (amide) 6 and low density poly (ethylene) filled with zinc oxide. E-Polymers. 8: 1467-1479.

Ghaly A.E., Arab F., Mahmoud N.S., Higgins J. (2007) Production of levan by Bacillus licheniformis for use as a soil sealant in earthen manure storage structures. Am. J. Biochem. Biotechnol. 3: 47-54.

Haldorai Y., Shim J.J. (2013) Chitosan-zinc oxide hybrid composite for enhanced dye degradation and antibacterial activity. Compos. Interfaces. 20: 365-377.

Helmlinger J., Sengstock C., Gross-Heitfeld C., Mayer C., Schildhauer T.A., Köller M., Epple M. (2016) Silver nanoparticles with different size and shape: equal cytotoxicity, but different antibacterial effects. RSC. Adv. 6(22): 18490-18501.

Imani M.M., Safaei M. (2019) Optimized Synthesis of Magnesium Oxide Nanoparticles as bactericidal agents. J. Nanotechnol. 2019: 6063832.

Khanafari A., Roohi A., Taghvaei Gangali S. (2010) Levan biopolymer production from Bacillus polymixa with viewpoint for usage in medical. Microbial. Biotech. 2: 35-40.

Kolodziejczak-Radzimska A., Jesionowski T. (2014) Zinc oxide from synthesis to application: a review. Materials. 7(4): 2833-2881.

Li B., Webster T.J. (2018) Bacteria antibiotic resistance: New challenges and opportunities for implant associated orthopedic infections. J. Orthop. Res. 36(1): 22-32.

Melo I.R., Pimentel M.F., Lopes C.E., Calazans G.M. (2007) Application of fractional factorial design to levan production by Zymomonas mobilis. Braz. J. Microbiol. 38: 45-51.

Mishra Y.K., Adelung R. (2018) ZnO tetrapod materials for functional applications. Mater. Today. 21(6): 631-651.

Mozaffari H.R., Izadi B., Sadeghi M., Rezaei F., Sharifi R., Jalilian F. (2016) Prevalence of oral and pharyngeal cancers in Kermanshah province, Iran: a ten-year period. Int. J. Cancer. Res. 12(3-4): 169-175.

Mozaffari H.R., Payandeh M., Ramezani M., Sadeghi M., Mahmoudiahmadabadi M., Sharifi R. (2017) Efficacy of palifermin on oral mucositis and acute GVHD after hematopoietic stem cell transplantation (HSCT) in hematology malignancy patients: a meta-analysis of trials. Wspolczesna. Onkol. 21(4): 299-305.

Mozaffari H.R., Zavattaro E., Abdolahnejad A., Lopez-Jornet P., Omidpanah N., Sharifi R., Sadeghi M., Shooriabi M., Safaei M. (2018) Serum and salivary IgA, IgG, and IgM levels in oral lichen planus: a systematic review and metaanalysis of case-control studies. Medicina 54(6): 99. 
Nomani H., Hagh-Nazari L., Aidy A., Vaisi-Raygani A., Kiani A., Rahimi Z., Bahrehmand F., Shakiba E., Mozaffari H.R., Tavilani H., Pourmotabbed T. (2016) Association between GSTM1, GSTT1, and GSTP1 variants and the risk of end stage renal disease. Ren. Fail. 38(9): 1455-1461.

Perez-Altamar M., Perales-Perez O. (2014) Fabrication and characterization of chitosan/cellulose-ZnOnanocomposites for bactericidal applications. MRS. Symp. Proc. 1685: 690-695.

Rad M., Taran M., Alavi M. (2018) Effect of incubation time, $\mathrm{CuSO}_{4}$ and glucose concentrations on biosynthesis of copper oxide $(\mathrm{CuO})$ nanoparticles with rectangular shape and antibacterial activity: Taguchi method approach. Nano Biomed. Eng. 10(1): 25-33.

Safaei M., Taran M. (2017) Fabrication, characterization, and antifungal activity of sodium hyaluronate-TiO2 bionanocomposite against Aspergillus niger. Mater. Lett. 207: 113-116.

Safaei M., Taran M., Imani M.M. (2019) Preparation, structural characterization, thermal properties and antifungal activity of alginate-CuO bionanocomposite. Mater. Sci. Eng. C. 101: 323-329.

Sato M., Kawata A., Morito S., Sato Y., Yamaguchi I. (2008) Preparation and properties of polymer/zinc oxide nanocomposites using functionalized zinc oxide quantum dots. Eur. Polym. J. 44(11): 3430-3438.

Seil J.T., Webster T.J. (2011) Antibacterial zinc oxide nanoparticles in polymer biomaterial composites. MRS. Symp. Proc. 1316: 128-133.
Sharifi R., Khazaei S., Mozaffari H.R., Amiri S.M., Iranmanesh P., Mousavi S.A. (2017) Effect of massage on the success of anesthesia and infiltration injection pain in maxillary central incisors: Double-blind, crossover trial. Dent. Hypotheses. 8(3): 61-64.

Shih I.L., Yuy T., Shieh C.J., Hsieh C.Y. (2005) Selective production and characterization of levan by Bacillus subtilis (Natto) Takahashi. J. Agric. Food. Chem. 23: 151-155.

Sikalidas C. (2011) Advances in ceramics-synthesis and characterization, processing and specific applications. InTech, Croatia. ISSN: 978-953-307-505-1

Silbir S., Dagbagli S., Yegin S., Baysal T., Goksungur Y. (2014) Levan production by $Z$ ymomonas mobilis in batch and continuous fermentation systems. Carbohydr. Polym. 99: 454-461.

Srikanth R., Reddy C.H.S., Siddartha G., Ramaiah M.J., Uppuluri K.B. (2015) Review on production, characterization and applications of microbial levan. Carbohydr. Polym. 120: 102-114.

Stoimenov P.K., Klinger R.L., Marchin G.L., Klabunde K.J. (2002) Metal oxide nanoparticles as bactericidal agents. Langmuir. 18: 6679-6686.

Taran M., Rad M., Alavi M. (2016) Characterization of $\mathrm{Ag}$ nanoparticles biosynthesized by Bacillus sp. HAI4 in different conditions and their antibacterial effects. J. Appl. Pharm. Sci. 6(11): 94-99.

Taran M., Rad M., Alavi M. (2018) Biosynthesis of $\mathrm{TiO}_{2}$ and $\mathrm{ZnO}$ nanoparticles by Halomonas elongata IBRC-M 10214 in different conditions of medium. BioImpacts 8(2): 81-89. 